\title{
Distinctive Innovation Capabilities of Argentine Software Companies with High Innovation Results and Impacts
}

\author{
María Isabel Camio ${ }^{1, *, \dagger}$, María del Carmen Romero ${ }^{1,+}$, María Belén Álvarez ${ }^{2,+}$ \\ and Alfredo José Rébori ${ }^{1, \dagger}$ \\ 1 UNICEN, Facultad de Ciencias Económicas, Centro de Estudios en Administración (CEA), Tandil, \\ Buenos Aires 7000, Argentina; romero@econ.unicen.edu.ar (M.d.C.R.); decano@econ.unicen.edu.ar (A.J.R.) \\ 2 CEA, CONICET, FCE-UNICEN (Pinto 399) Tandil, Buenos Aires 7000, Argentina; \\ maria.alvarez@econ.unicen.edu.ar \\ * Correspondence: camio@econ.unicen.edu.ar; Tel.: +54-249-438-5550 \\ + These authors contributed equally to this work.
}

Received: 4 January 2018; Accepted: 6 April 2018; Published: 13 April 2018

\begin{abstract}
The software sector is of growing importance and, due to its degree of dynamism, the identification of capabilities for innovation is vital. This study identifies capabilities variables that distinguish Argentine software companies with high innovation results and high innovation impacts from those with lesser results and impacts. It is applied to a sample of 103 companies, a measurement model and the component variables of an innovation degree index for software companies (INIs) formulated in previous studies. A Principal Component Analysis and a biplot are conducted. In the analysis of results and impacts, $100 \%$ of the variability within the first two components is explained, which shows the high correlation between variables. From the biplots, it appears that companies with high results have higher degrees in the variables of motivation, strategy, leadership and internal determinants; and those with high impacts present higher degrees of structure, strategy, leadership, free software and innovation activities. The findings add elements to the theory of capabilities for innovation in the software sector and allow us to consider the relative importance of different capabilities variables in the generation of innovation results and impacts.
\end{abstract}

Keywords: innovation; capabilities; software; results; impacts

\section{Introduction}

The software sector has been growing in importance in countries likes Argentina. Innovation generation becomes of vital importance in sectors with constant changes, which can reformulate strategic positions. In this context, and particularly for smaller companies, the identification of key capabilities for results achievement and innovation related impact becomes a key feature in terms of research objectives.

In the current business context, which is highly competitive and involves products and technology with short life cycles, it is essential for the software industry to manage innovation systematically. In this context, the management of innovation is decisive and at the same time requires analysis and intervention tools that allow identification of the key variables to be taken into account in order to improve the results and impacts of innovation.

The measurement of innovative activity and its effects is an area that, for a long time, has concerned those economists interested in analyzing innovation processes and their relationship with global economic dynamics. On the one hand, there is the question of how to measure "innovative activity" in itself. On the other hand, there is a concern to know how this innovative activity influences 
the rate of growth of productivity and the economy. The massive introduction of "new technologies" and the transition to a knowledge-based society have increased the interest in investigating these subjects (López 1998).

This is extremely necessary in developing economies, in which it is necessary to focus analysis on the capacities, since in some cases these capacities do not have a direct association, at a given moment, with the innovation results achieved by the companies.

Different research analyzes innovative capabilities and relates them to other variables in different contexts and types of organizations; for example, Dolsen and Chinnam (2017) study the development of innovation capability in a mass production organization. Liao et al. (2010) investigate the relationships between knowledge acquisition, absorptive capability and innovation capability in Taiwans knowledge-intensive industries. Akman and Yilmaz (2008) examine the relations among market orientation, innovation strategy, innovative capability and innovation success in small and medium enterprises (SMEs) in developing countries.

In the specific context of software firms, studies such as that by Romijn and Albaladejo (2002) explore the determinants of innovation capability that might have contributed to the companies' innovative performance in 33 small UK electronics and software firms. Capaldo et al. (2003) propose a methodology that permits the evaluation of innovation capabilities in small software firms.

Research like that mentioned above focus on the study of innovation capabilities in specific contexts. Nevertheless, there is no research that focuses on identifying which capabilities in innovation management have been developed, and distinguish, companies with high innovation results and high innovation impacts. This gap becomes greater when addressing the study of software firms, especially in the context of Argentina.

Research questions arise from this work, such as: What capabilities have software companies developed with high innovation results and innovation impact? Are there differences in the degree of skills developed among companies with low, medium and high innovation results and innovation impact?

Based on the questions presented above, the following objective arises: Identifying the capabilities variables that distinguish Argentine software companies with high innovation results and high innovation impacts from those with lower results and impacts.

\section{Literature Review}

Drucker (1954; cited by Cavusgil et al. 2003) was one of the first scholars to address the importance of innovation capability for organizations. He suggested that a firm has to be innovative to survive in the volatile environment.

Through the content analysis of 51 articles from 30 journals published between 2000 and 2015, focusing on how innovation capability is defined, Iddris (2016) suggests that there is a lack of consensus regarding its definition. He states that generally the authors made reference to the terms knowledge transformation, learning, idea generation and processes.

Innovation capability is proposed as a higher-order integration capability, that is, the ability to mold and manage multiple capabilities. Organizations possessing this innovation capability have the ability to integrate key capabilities and resources of their firm to successfully stimulate innovation (Lawson and Samson 2001).

Amabile et al. (1996; cited by Zhao et al. 2005) state that innovation capability is the application of relevant knowledge to the attainment of market value and is the successful implementation of creative ideas within an organization.

In their acknowledged studies, Teece and Pisano (1994) and Teece et al. (1997) suggest that the winners in the global marketplace have been firms that demonstrate timely responsiveness and rapid and flexible product innovation, along with the management capability to effectively coordinate and redeploy internal and external competences. They call this source of competitive advantage, 'dynamic capabilities.' 
The term 'dynamic' refers to the shifting character of the environment; certain strategic responses are required when time-to-market and timing is critical, the pace of innovation is accelerating and the nature of future competition and markets is difficult to determine. The term 'capabilities' emphasizes the key role of strategic management in appropriately adapting, integrating and re-configuring internal and external organizational skills, resources and functional competences towards a changing environment (Teece and Pisano 1994; Teece et al. 1997).

Eisenhardt and Martin (2000) focus on the approach of dynamic capabilities in the more general framework of the resource-based perspective. These dynamic capabilities are of specific strategic and organizational processes, which create value for companies within dynamic markets by manipulating resources towards new value creation strategies.

In her study of innovative capability development in U.S. and Japanese firms, Un (2002) points out that the firm's innovative capability is its ability to mobilize the knowledge embodied in its employees (Kogut and Zander 1992; cited by Un 2002) and combine it to create new knowledge resulting in product and/or process innovation. She states that this capability is dynamic in that it involves the interaction between a firm's internal knowledge and the demands of the external market.

According to Lin et al. (2016), previous research emphasizes the relationship between dynamic capabilities and innovation (for example, Ambrosini et al. 2009; Aragón-Correa and Sharma 2003; Cheng and Chen 2013; Clausen 2013; Hart and Dowell 2010; Helfat et al. 2007; Kohlbacher 2013; Ridder 2011; Teece 2007; Teece et al. 1997) and argue that a company's dynamic capabilities could significantly improve its ability to innovate (O'Conner 2008; cited by Lin et al. 2016), especially in the case of radical innovations.

Lawson and Samson (2001) suggest that dynamic capabilities theory is well-suited to the study of organizational innovation because there is no special focus on technology. For example, research and development is but one resource among many available to the firm. This facilitates development of a holistic model of organizational innovation.

Some studies, such as that by Miranda and Figueiredo (2010), contribute to the study of innovation specifically in the context of technological companies, such as those in the software sector. These authors (Miranda and Figueiredo 2010) define technological capability as the necessary resources (knowledge stock) to generate and manage innovative activities, products, processes and the organization of production, organizational systems, equipment and engineering projects-in other words, technological change.

Miranda and Figueiredo (2010) distinguish routine and innovative companies based on the degree of technological capabilities achieved by the firms. For each of the degrees, the identification of the relationship of the processes with quality measures, certifications and continuous improvement of the processes, the type of products or services and the type of software engineering tools used are highlighted.

Other research states that knowledge is related to absorption capability ${ }^{1}$ and that the absorption capability of a company has a significant impact on its ability to innovate (Chang et al. 2012; Ralpha and Hurmelinna-Laukkanen 2013; cited by Cheng et al. 2016). Therefore, a company with a well-developed absorptive capability can strengthen its knowledge base and adapt to environmental changes by renewing its products (Liao et al. 2003; cited by Cheng et al. 2016).

Addressing the variables that condition the ability to generate innovation, studies such as that by Lawson and Samson (2001) suggest that there is no one generic formula of innovation capability. There are, however, common threads running between highly and lowly innovative firms that vary only in degrees of importance (Tidd et al. 1997; cited by Lawson and Samson 2001).

1 Cohen and Levinthal (1990), in their seminal work, propose the concept of absorption capability, defined as the ability to exploit external knowledge, a critical component of innovative capabilities. 
According to those authors, the elements making up an innovation capability are grouped into seven major elements: vision and strategy, harnessing the competence base, organizational intelligence, creativity and idea management, organizational structure and systems, culture and climate and the management of technology (Lawson and Samson 2001).

In his study, Saunila (2017) defines innovation capability through aspects influencing an organization's capability to manage innovation. These aspects include participatory leadership culture, ideation and organizing structures, work climate and well-being, know-how development, regeneration, external knowledge and individual activity.

Recent studies, particularly in the context of software companies, identify among the capabilities variables: strategy, structure, software tools, communication and other variables such as internal determinants-culture, background and skills, qualification of human resources, among others-and external determinants, which include the relationship with external actors and external barriers (Camio et al. 2016).

Engaging consciously and purposively in a business strategy supporting innovation defines systematic innovation capability. The business strategy determines the extent to which innovation is central to a business' competitive strategy (Keupp et al. 2011; Teece 2010; Ritter and Gemunden 2003; Rohrbeck and Gemunden 2011; Le Masson et al. 2010; cited by Samson et al. 2017).

Strategy has a decisive role in innovation, particularly the "orientation towards the future" (Tamm 2010; cited by Rueda-Cáceres and Sánchez-Torres 2015) and the "long-term strategic approach" (Tellis et al. 2009). On the other hand, Leavy (2005) emphasizes that many companies include a commitment to innovation in their mission statements. In addition, it should be noted that an innovation vision must be aligned with other strategic elements (Dobni 2008).

Guided by this strategic direction, organizations grow their innovation capability through a strong customer focus and external relationships that signify an open approach to innovation and resource innovation across their activities and operations (Samson et al. 2017).

According to the Oslo Manual (OECD and Eurostat 2005), a firm's organizational structure can affect the efficiency of innovation activities. A greater degree of organizational integration may improve the coordination, planning and implementation of innovation strategies. Organizational integration can work particularly well in industries characterized by incremental changes in knowledge and technologies. A looser, more flexible form of organization, which allows workers greater autonomy to make decisions and define their responsibilities, might be more effective in generating more radical innovations.

In line with the above, Crossan and Apaydin (2010; cited by Rueda-Cáceres and Sánchez-Torres 2015) understand that the more permeable and organic the structure, the greater the possibility that innovative ideas will emerge.

Other variables, such as the relationship between the processes and quality measures, certifications and continuous improvement of the processes, the type of products or services and the type of software engineering tools used, are highlighted in the study by Miranda and Figueiredo (2010) who, as we mentioned above, distinguish routine and innovative companies based on the degree of technological capabilities achieved by the firms.

When analyzing absorption capability, Cohen and Levinthal (1990) indicate that to understand the sources of a firm's absorptive capability, the focus needs to be on the structure of communication between the external environment and the organization, as well as among the subunits of the organization and also on the character and distribution of expertise within the organization. Empirical studies have shown that higher degrees of communication and information gathering are associated with organizational innovation (Aiken and Hage 1971; Evan and Black 1967; Kanter (1982, 1988); Tjosvold and Mcneely 1988; cited by Monge et al. 1993) and with higher degrees of performance with the groups of R\&D projects (Katz 1982; Keller 1986; Keller and Holland 1983; Pelz and Andrews 1966; cited by Monge et al. 1993).

Other drivers of innovation results are linked to higher degrees of fluency, breadth and depth in the processes of organizational communication (Aramburu and Sáenz 2010). Issues such as trust, 
empowerment, open communication and a greater degree of freedom become essential in encouraging innovative activity through collaboration and individual satisfaction (Lemon and Sahota 2004).

Aramburu and Sáenz (2010) present a model that contrasts, among others, the hypothesis that the agility and fluency in the channels of horizontal and vertical communication and the physical design of workplaces (organizational design) act as catalysts for knowledge sharing in management processes. According to its results, both the information flows and the organizational culture significantly influence the results of innovation, especially in medium-high and high technology companies.

In a systematic review, Iddris (2016) identifies different studies that have all recognized organizational culture as a driving force for innovation capability (for example, Lawson and Samson 2001; Çakar and Ertürk 2010; and Martins and Terblanche 2003). He points out that an organization that promotes the empowerment of employees, tolerance, effective communication between focal firms and significant partners and a positive attitude towards achieving organizational goals can be seen to promote an innovation culture.

According to Lemon and Sahota (2004), organizational culture has been recognized as a primary determinant within innovation and the need to better understand this relationship or process is a necessary prerequisite to nurturing it in a more structured and systematic manner. Innovation is holistic in nature and is inseparable from the culture that facilitates or constrains the ability to 'add value.'

The use of team-based working is dependent on other factors, such as an open and collaborative organizational culture and a participatory management style; thus, employees working in teams will be more open to discussing and implementing new ideas within their teams (Smith et al. 2008).

In their study of capabilities critical to innovation performance for 131 very small high-tech firms Börjesson and Löfsten (2012; cited by Akinwale et al. 2018) include, among others, capabilities variables such as education level of the employees and employer and their work experience.

A high educational attainment should provide individuals with necessary background knowledge about the current state of science and technology. In addition, it should provide highly educated people with the training to recognize, analyze and solve complex problems, all of which contribute towards individual ability to conceive innovative business ideas (Koellinger 2008).

Romijn and Albaladejo (2002), in specific studies of small electronics and software companies, found that the proportion of engineers with university education over the total number of employees correlates positively with the index of central product innovations. They also identified internal resources, such as the background of founders or managers, as determinants of innovation capability. Studies conducted by Koc (2007) identify that the depth and variety of skills and experiences of employees are considered to be important elements of innovation in the software companies examined.

Along the same lines, Carter et al. (2001), in their software company research found in staff training an important resource, a formal mechanism that generally had positive impact on adoption.

Through strong senior executive leadership and role modelling of innovation, organizational behavior and culture are deeply embedded within an innovation "mindset" that permeates the entire organization (Samson et al. 2017).

In reference to different studies, Chang et al. (2015) points out that leadership is considered one of the most important factors that affect innovation, as leaders not only influence organizational characteristics such as culture, strategy, structure, reward systems and resources (Mumford et al. 2002; cited by Chang et al. 2015) but also encourage creativity in their followers (Jung 2001; cited by Chang et al. 2015; Gumusluoglu and Ilsev 2009).

Specific studies, such as that by Gumusluoglu and Ilsev (2009)—on micro and small software companies—and that by Jung et al. (2003)—on electronics and telecommunications companies-deepen the study of the style of transformational leadership and its relationship with organizational innovation. According to Bass (2000), transformational leaders have a vision that motivates their followers, increases their willingness to work beyond expectations and challenges them to adopt innovative approaches in their work (Gumusluoglu and Ilsev 2009). 
Hotho and Champion (2011; cited by Saunila 2017) point out that people who have creativity and intrinsic motivation (as well as skills) for their work will be favorable for creating a work environment that supports the creation of innovations.

In a study that links knowledge management and organizational innovativeness, Sajeva and Jucevicius (2008) assume that the innovative organization supports creative individuals and provides the conditions in which they can share and create knowledge. In this context, they state that the main goal of an organization is to create an environment that could motivate individuals to be more innovative and to use knowledge creatively, to share their knowledge and to collaborate in producing and adopting new innovations. Innovative firms should also align an organization's rewards and recognition with the goals of innovation (Sajeva and Jucevicius 2008).

The literature supports the view that employees that are empowered and autonomous have a greater degree of control over their work. This degree of control means that employees feel comfortable in their role to be innovative in their own work environment (Thamhain 1990; Tang 1999; Zwetsloot 2001; Amar 2004; Mostafa 2005; Muthusamy et al. 2005; Nystrom et al. 2002; cited by Smith et al. 2008).

According to Sulistyo (2016), empowerment significantly influences innovation capabilities and performance. The better the empowerment in terms of decision-making authority, access to information, providing positive impact and following the planning process will encourage innovation capabilities and the performance. This supports the findings by Çakar and Ertürk (2010; cited by Sulistyo 2016) who conclude that empowerment directly affects innovation capabilities.

The optimal incentive scheme that motivates innovation exhibits substantial tolerance (or even reward) for early failure and reward for long-term success. Also, commitment to a long-term compensation plan, job security and timely feedback on performance are essential ingredients to motivate innovation (Manso 2011).

Regarding innovation activities, the Frascati Manual (OECD 2002) states that technological innovation activities are the set of scientific, technological, organizational, financial and commercial stages, including investments in new knowledge for the implementation of new or improved products and processes.

In reference to different studies, Samson et al. (2017) point out that innovation activities and operations that support the implementation of innovation processes include research and development (Enkel et al. 2009), creativity and lateral thinking (Hilles et al. 2009; Abraham and Knight 2001; Amabile et al. 1996) and a commitment to quality philosophy and practices (Lages et al. 2009; Revelle 2010; Kim et al. 2012; Perdomo-Ortiz et al. 2006).

$R \& D$ is just one of the innovation activities and can be carried out in different phases of the innovation process. The software that is part of an $R \& D$ project must be classified as $R \& D$, the $R \& D$ activities associated with a software if it constitutes a finished product, the upgrade to a more powerful version and the improvement or modification of a program or an existing system (OECD 2002).

The Frascati Manual (OECD 2002) proposes that staff data measure the volume of resources devoted directly to R\&D activities and the expenditure data measure the total cost of R\&D execution, including the cost of indirect (auxiliary) support activities.

In his work on three high-tech industries, Wagner (2011) refers to the fact that one of the measures of $R \& D$ activities is the intensity of $R \& D$, that is, the ratio between $R \& D$ expenditure and sales; this variable is frequently proposed as a measure of innovation effort and input (Brouwer and Kleinknecht 1999; Deeds 2001 cited by Wagner 2011).

Another aspect to consider is the use of free software and its impact on the generation of innovation. Open source software (OSS) is viewed as one of the most well-established examples of both open innovation (Morgan et al. 2013; West 2007; Gassmann and Enkel 2004; cited by Morgan and Finnegan 2014) and commons-based peer production (Feller et al. 2008; Benkler 2002; cited by Morgan and Finnegan 2014). 
Generally, as part of an open innovation strategy, firms are increasingly treating open source software (OSS) communities as a complementary asset to be leveraged and combined with the firm's own internal assets to deliver competitive solutions (Dahlander and Wallin 2006; cited by Teigland et al. 2014).

Emphasizing that innovation is a social and interactive process underline the importance of establishing reliable and long-lasting communication channels, both within the firm and with external agents such as suppliers, customers, competitors, universities, research institutes and so forth. (López and Lugones 1997).

As a result of his study on knowledge intensive firms, Indarti (2017) suggests that the more capable a firm is of grasping external knowledge, the better it is able to utilize this information in the development of innovative products. Interaction enables firms to access knowledge from various kinds of external innovation partners who can provide access to widely differing knowledge domains such as technology, design, customer insights and market trends (Brunswicker and Vanhaverbeke 2015; cited by Indarti 2017).

According to Chesbrough (2003), Open Innovation means that valuable ideas can come from inside or outside the company and can go to market from inside or outside the company as well. This approach places external ideas and external paths to market on the same level of importance as the reserved for internal ideas and paths to market during the Closed Innovation era.

The threefold idea behind open innovation is that firms are part of an environment characterized by knowledge distributed over various actors, external knowledge is accessible through a multitude of channels, and the innovation process itself, in order to be successful, has to be distributed across a number of actors (Bigliardi and Galati 2016).

Networking with other organizations, whether long-term or short-term, can result in an organization's attitude to innovation changing (Hadjimanolis 2000; Kandampully 2002; Pavitt 2002; Flor and Oltra 2004; Jaskyte and de Riobó 2004; Medina et al. 2005; Mudrak et al. 2005; cited by Smith et al. 2008).

Within the framework of external determinants, the factors that may hinder or slow down innovative activity are considered. The Bogota Manual (RICYT et al. 2001) mentions factors such as legislation, labor standards and regulations, poor response from customers to new processes and products, information about technologies and the ability to imitate innovations.

According to Drucker (1954; cited by Cavusgil et al. 2003), innovation capabilities are critical to achieving superior innovation performance. This is because markets are characterized by short products life cycle and a high rate of new product introduction. A firm with a great innovation capability will enjoy a high innovation performance.

Innovation results degree refers to innovation types of products, processes, commercialization and organization and to its novelty degree (new to the world, the market, the industry, the company) (OECD and Eurostat 2005).

In their empirical study on three Brazilian companies in the ICT sector, Comin et al. (2015) identify that innovation management processes aligned with the company's strategy can be associated with improved business performance.

Other research has focused on the impact of the results of radical innovation on the success of new products and the performance of companies (for example, Chandy and Tellis 2000; Han et al. 1998; Sorescu et al. 2003; Sorescu and Spanjol 2008; cited by Baker et al. 2014).

According to its nature, innovation can have very different impact on the results of companies and economic progress. This is the reason why it is important to be able to identify the introduction and impact of different types of innovation (OECD and Eurostat 2005). Innovation impact on company results range from the effects on sales and market share to the improvement of productivity and efficiency (OECD and Eurostat 2005). 


\section{Methods}

A descriptive analysis is carried out based on the results of a study on a sample of Argentine software companies.

An innovation measurement model, previously developed, is applied (Camio et al. 2015), which includes three dimensions: capabilities, results and impacts of innovation (Table 1).

Table 1. Innovation measurement model: dimensions and variables.

\begin{tabular}{|c|c|}
\hline Dimensions & Variables \\
\hline CAPABILITIES & $\begin{array}{ll}\text { - } & \text { Structure } \\
\text { - } & \text { Software tools } \\
\text { - } & \text { Strategy } \\
\text { - } & \text { Communication } \\
\text { - } & \text { Leadership } \\
\text { - } & \text { Motivation } \\
\text { - } & \text { Free software } \\
\text { - } & \text { Innovation activities } \\
\text { - } & \text { Internal determinants } \\
\text { - } & \text { External determinants }\end{array}$ \\
\hline RESULTS & $\begin{array}{ll}\text { - } & \text { Products } \\
\text { - } & \text { Processes } \\
\text { - } & \text { Organization } \\
\text { - } & \text { Marketing } \\
\end{array}$ \\
\hline IMPACTS & $\begin{array}{ll}\text { - } & \text { Performance measures } \\
\text { - } & \text { Generation of intangibles }\end{array}$ \\
\hline
\end{tabular}

In order to select the variables for the construction of the innovation measurement model, it was realized a literature review regarding distinctive elements of the measurement of innovation for the software sector (especially the R\&D concept) and it was analyzed the data collected in previous studies (Romero et al. 2010). ${ }^{2}$

Consequently, for the collection of data, a structured questionnaire with 133 questions was designed. This instrument was validated both in terms of internal and external validity.

The questions proposed for the questionnaire were (internally) validated in order to assess their degree of representation with respect to the content universe of which they are a part. This validation was carried out by the researchers themselves based on their prior knowledge and taking into account the theoretical framework that was developed ad hoc. In addition, key informants from the sector (researchers, businessmen, representatives of intermediate organizations) were consulted and aspects surveyed from other studies in Latin American contexts were considered.

Reliability was corroborated by the method of internal consistency (or average interrelation); Cronbach's alpha showed a value equal to 0.85 , which means that the instrument (analyzed at the degree of base variables) is reasonably reliable.

Given the lack of a single database of software companies in Argentina, for the present study, an ad hoc database was created that includes 699 companies. Answers were obtained from 103 companies (response rate: $14.73 \%$ ). Due to the characteristics of the sample considered, the analysis carried out and the findings obtained are limited to this group of companies.

The capabilities variables included in the analysis are ten and are specified in Table 2.

2 In the cited work, the proposal of an index of level of innovation (INI) was studied, which was applied in the context of an exploratory study of multiple cases (Yin 2009) to Argentinian SMEs companies from different sectors. From the data collected on that occasion, those referred to the subgroup of software companies were analyzed in depth in order to identify recurrent problems in obtaining them. 
Table 2. Capabilities variables and subvariables.

\begin{tabular}{|c|c|c|}
\hline \multicolumn{2}{|c|}{ Variable } & \multirow[t]{2}{*}{ Subvariables } \\
\hline Name & ID. Variable & \\
\hline Structure & V1_Struct & $\begin{array}{ll}\text { - } & \text { Departments of } \mathrm{R}+\mathrm{D}+\text { quality } \\
\text { - } & \text { Structure characteristics } \\
\text { - } & \text { Networking } \\
\text { - } & \text { Process degree }\end{array}$ \\
\hline Software tools & V2_Tools & $\begin{array}{ll}\text { - } & \text { Tools degree } \\
\text { - } & \text { Documentation and methodology }\end{array}$ \\
\hline Strategy & V3_Strat & $\begin{array}{ll}\text { - } & \text { Strategic priorities } \\
\text { - } & \text { Customer orientation } \\
\text { - } & \text { Innovation management } \\
\text { - } & \text { Strategic / innovation decisions } \\
\text { - } & \text { Portfolio of products and services } \\
\end{array}$ \\
\hline Communication & V4_Communic & $\begin{array}{ll}\text { - } & \text { Circulation of communication } \\
\text { - } & \text { Communication frequency } \\
\text { - } & \text { Transfer of innovation decisions } \\
\end{array}$ \\
\hline Leadership & V5_Leader & - $\quad$ Selection and ranking of the 5 most important features of leaders \\
\hline Motivation & V6_Motiv & $\begin{array}{l}\text { - } \quad \text { Generation of innovative ideas } \\
\text { - }\end{array}$ \\
\hline Free software & V7_FreeSoft & $\begin{array}{ll}\text { - } & \text { Knowledge / use of free software } \\
\text { - } & \text { Reasons for free software use }\end{array}$ \\
\hline Innovation activities & V8_InnAct & $\begin{array}{ll}\text { - } & \text { Innovative people / activities (and time) } \\
\text { - } & \text { Innovation budget / activities } \\
\text { - } & \text { Degree of products and services }\end{array}$ \\
\hline Internal determinants & V9_IntDet & $\begin{array}{ll}\text { - } & \text { Culture } \\
\text { - } & \text { Background and skills } \\
\text { - } & \text { Internal barriers } \\
\text { - } & \text { HR qualification } \\
\text { - } & \text { Training } \\
\end{array}$ \\
\hline External determinants & V10_ExtDet & $\begin{array}{ll}\text { - } & \text { Relationship with external actors } \\
\text { - } & \text { External barriers } \\
\end{array}$ \\
\hline
\end{tabular}

For the evaluation of results and impacts of innovation in the companies studied, the following variables are taken into consideration:

\section{- Results:}

- Products: Introduction of new or significantly enhanced products, degree of novelty of products and changes in the central characteristics of the product.

- Processes: Introduction of new processes and significance of process improvements.

- Organization: Organizational innovations and types of organizational innovations carried out.

- Marketing: Marketing innovations and types of marketing innovations carried out.

\section{- Impacts/performance:}

- $\quad$ Performance measures: Sales share percentage of innovated products, impact of product innovations, impact of process innovations, impact of organizational innovations, impact of marketing innovations.

- Generation of intangibles: requested patents, obtained patents, licensed technology, free software licenses use, quality certification.

The data collected from the questions of the questionnaire are qualitative and quantitative and belong to different measurement scales (nominal, ordinal, interval or ratio). Based on these questions, 
base variables were constructed (subvariables-Table 2), which are all qualitative ordinals with 5 possible values: very high, high, medium, low and very low. These values were assigned creating a correspondence between the responses of the original variables and the contribution of these responses to the degree of innovation. This step is carried out ad hoc considering empirical and conceptual criteria (Camio et al. 2016).

The ordinal qualitative variables (subvariables) provide answers to the variables of higher degrees (variables-Tables 1 and 2). Each higher degree variable results in an index constructed from the combination of subvariables; each subvariable was assigned a numerical rating according to the following: very high: 5, high: 4, medium: 3, low: 2 and very low: 1 . Each index was constructed considering the sum of the component subvariable valuations weighted by their degree of importance. Since they are indexes, all the variables of higher degrees are quantitative.

Capabilities variables are considered according to the above specification. Result and impact variables are used to classify the companies studied into 3 degrees (high, medium and low) according to the values of the index.

The perspective of the proposed analysis considers the linkages between the capability dimension and the dimensions considered as result in the aforementioned model, particularly the results and impacts of innovation.

Correlation matrices expose the correlations between the ten variables (taken in pairs) for both the innovation result groups and the innovation impact groups. (Table 3a,b).

In order to respond to the stated objective and, given the quantitative nature of the data-indices created ad-hoc-(Camio et al. 2016), a Principal Component Analysis (PCA) and a biplot were carried out. The 103 cases studied are considered, divided into three groups of results in each case. Using the same technique are analyzed, on the one hand, the group of companies with high results of innovation, with medium results of innovation and with low results of innovation. On the other hand, the three groups of companies with different degrees (low, medium and high) of innovation impact are analyzed in the same way.

The Principal Component Analysis tries to explain the entire variance-covariance structure of a set of variables through a few linear combinations of those variables. The biplots graphics proposed by Gabriel (1971) show the observations and the variables in the same graph, so that interpretations can be made about the joint relationships between observations and variables.

In biplots, the distance between symbols representing observations and symbols representing variables has no interpretation but the directions of the symbols from the origin can be interpreted. The observations (row points) plotted in the same direction as a variable (column point) could have relatively high values for that variable and low values in variables or column points that are plotted in the opposite direction. The angles between the vectors that represent the variables can be interpreted in terms of the correlations between variables (Balzarini et al. 2008).

To contribute to the analysis of the data, summary measures were calculated for each of the variables of capabilities in analysis, taking into account the different degrees (low, medium and high) both in relation to innovation results and in relation to the impacts of innovation. The average and the minimums and maximums in each case were particularly considered. This is shown in Table 7.

The statistical software InfoStat (Di Rienzo et al. 2016) was used for the analysis.

\section{Results}

Taken into account the aim of identifying capabilities variables that distinguish those Argentine software companies with high innovation results and high innovation impacts from those with lower innovation results and innovation impacts and following the methodology described above, first we expose the correlations between the capabilities variables for both the innovation result groups and the innovation impact groups and then the results of the Principal Component Analysis (PCA) and a Biplot were carried out. 
From the analysis of correlation between the ten capabilities variables for the groups determined for innovation results, correlations higher than 0.9 arise (in all cases with a positive sign) (Table 3a): V1_Struct and V2_Tools, V1_Struct and V7_FreeSoft (with value 1: perfect direct linear dependence), V1_Struct and V9_IntDet, V2_Tools and V7_FreeSoft, V2_Tools and V8_InnAct, V3_Strat and V5_Leader, V3_Strat and V6_Motiv (with value 1: perfect direct linear dependence), V5_Leader and V6_Motiv, V5_Leader and V9_IntDet, V7_FreeSoft y V8_InnAct.

The same analysis for the groups determined for innovation impacts, yields correlations greater than 0.9 between the capability variables (with a positive sign) (Table 3b): V1_Struct and V2_Tools, V1_Struct and V3_Strat, V1_Struct and V5_Leader, V1_Struct and V7_FreeSoft, V1_Struct and V2_ActInnov, V3_Strat and V5_Leader, V3_Strat and V7_FreeSoft, V3_Strat and V8_InnAct (with value 1: perfect direct linear dependence), V4_Communic and V9_IntDet, V5_Leader and V7_FreeSoft (with value 1: perfect direct linear dependence), V5_Leader and V8_InnAct (with value 1: perfect direct linear dependence), V7_FreeSoft and V8_InnAct, V7_FreeSoft and V9_IntDet.

Correlations with values higher than 0.90 and with negative sign (Table 3b): V4_Communic and V10_ExtDet, V7_FreeSoft and V10_ExtDet, V9_IntDet and V10_ExtDet (Table 3b).

Table 3. (a) Correlation Matrix/Analysis of Results. (b) Correlation Matrix/Analysis of Impacts.

\begin{tabular}{|c|c|c|c|c|c|c|c|c|c|c|}
\hline \multicolumn{11}{|c|}{ (a) } \\
\hline & V1 & V2 & V3 & V4 & V5 & V6 & V7 & V8 & V9 & V10 \\
\hline V1_Struct & 1.00 & & & & & & & & & \\
\hline V2_Tools & 0.98 & 1.00 & & & & & & & & \\
\hline V3_Strat & 0.64 & 0.45 & 1.00 & & & & & & & \\
\hline V4_Communic & -0.02 & -0.24 & 0.76 & 1.00 & & & & & & \\
\hline V5_Leader & 0.81 & 0.66 & 0.97 & 0.57 & 1.00 & & & & & \\
\hline V6_Motiv & 0.60 & 0.42 & 1.00 & 0.78 & 0.96 & 1.00 & & & & \\
\hline V7_FreeSoft & 1.00 & 0.99 & 0.57 & -0.10 & 0.76 & 0.54 & 1.00 & & & \\
\hline V8_InnAct & 0.88 & 0.96 & 0.18 & -0.50 & 0.43 & 0.14 & 0.91 & 1.00 & & \\
\hline V9_IntDet & 0.92 & 0.82 & 0.88 & 0.36 & 0.97 & 0.86 & 0.89 & 0.62 & 1.00 & \\
\hline V10_ExtDet & -0.47 & -0.65 & 0.38 & 0.89 & 0.13 & 0.42 & -0.54 & -0.84 & -0.10 & 1.00 \\
\hline \multicolumn{11}{|c|}{ (b) } \\
\hline & V1 & V2 & V3 & V4 & V5 & V6 & V7 & V8 & V9 & V10 \\
\hline V1_Struct & 1.00 & & & & & & & & & \\
\hline V2_Tools & 0.90 & 1.00 & & & & & & & & \\
\hline V3_Strat & 1.00 & 0.88 & 1.00 & & & & & & & \\
\hline V4_Communic & 0.52 & 0.09 & 0.56 & 1.00 & & & & & & \\
\hline V5_Leader & 0.98 & 0.80 & 0.99 & 0.68 & 1.00 & & & & & \\
\hline V6_Motiv & 0.53 & 0.84 & 0.48 & -0.45 & 0.35 & 1.00 & & & & \\
\hline V7_FreeSoft & 0.97 & 0.76 & 0.98 & 0.72 & 1.00 & 0.29 & 1.00 & & & \\
\hline V8_InnAct & 0.99 & 0.84 & 1.00 & 0.61 & 1.00 & 0.43 & 0.99 & 1.00 & & \\
\hline V9_IntDet & 0.76 & 0.41 & 0.80 & 0.95 & 0.88 & -0.15 & 0.90 & 0.83 & 1.00 & \\
\hline V10_ExtDet & -0.75 & -0.39 & -0.78 & -0.95 & -0.87 & 0.17 & -0.90 & -0.82 & -1.00 & 1.00 \\
\hline
\end{tabular}

Principal Component Analysis was applied to explore the capability variables according to the degree of innovation results (low, medium and high). It appears that the first component explains $64 \%$ of the variability and in conjunction with the second component they explain $100 \%$ (Table 4a). In the first component, the variables with greater weight are V1_Struct, V2_Tools, V3_Strat, V5_Leader, V7_FreeSoft and V9_IntDet; in the second component, V4_Communic and V10_ExtDet (Tables 5a and 6a). 
Table 4. (a) Eigenvalues/Analysis of Results. ${ }^{3}$ (b) Eigenvalues / Analysis of Impacts. ${ }^{4}$

\begin{tabular}{cccc}
\hline \multicolumn{3}{c}{$(\mathbf{a})$} \\
\hline Lambda & Value & Proportion & Cum Prop \\
\hline 1 & 6.38 & 0.64 & 0.64 \\
2 & 3.62 & 0.36 & 1.00 \\
\hline \multicolumn{4}{c}{$(\mathbf{b})$} \\
\hline Lambda & Value & Proportion & Cum Prop \\
\hline 1 & 7.67 & 0.77 & 0.77 \\
2 & 2.33 & 0.23 & 1.00 \\
\hline
\end{tabular}

Table 5. (a) Eigenvectors/Analysis of Results. (b) Eigenvectors/Analysis of Impacts.

\begin{tabular}{lcc}
\hline \multicolumn{1}{c}{ (a) } & & \\
\hline V1_Struct & e1 & e2 \\
V2_Tools & 0.38 & -0.13 \\
V3_Strat & 0.35 & -0.23 \\
V4_Communic & 0.32 & 0.31 \\
V5_Leader & 0.09 & 0.51 \\
V6_Motiv & 0.37 & 0.20 \\
V7_FreeSoft & 0.31 & 0.33 \\
V8_InnAct & 0.38 & -0.17 \\
V9_IntDet & 0.29 & -0.36 \\
V10_ExtDet & 0.39 & 0.08 \\
\hline & -0.10 & 0.51 \\
\hline \multicolumn{1}{c}{$\quad$ Variables } & e1 & \\
\hline V1_Struct & 0.35 & 0.15 \\
V2_Tools & 0.28 & 0.41 \\
V3_Strat & 0.36 & 0.12 \\
V4_Communic & 0.25 & -0.47 \\
V5_Leader & 0.36 & 0.02 \\
V6_Motiv & 0.11 & 0.62 \\
V7_FreeSoft & 0.36 & -0.02 \\
V8_InnAct & 0.36 & 0.08 \\
V9_IntDet & 0.32 & -0.30 \\
V10_ExtDet & -0.32 & 0.31 \\
\hline
\end{tabular}

4 Only the first two eigenvalues are exposed since the others are equal to 0.

3 Only the first two eigenvalues are exposed since the others are equal to 0. 
Table 6. (a) Correlations with the original variables/Analysis of Results. (b) Correlations with the original variables/Analysis of Impacts.

\begin{tabular}{lcc}
\hline \multicolumn{1}{c}{ (a) } & & \\
\hline V1_Struct & PC $\mathbf{1}$ & PC 2 \\
V2_Tools & 0.97 & -0.24 \\
V3_Strat & 0.89 & -0.45 \\
V4_Communic & 0.80 & 0.59 \\
V5_Leader & 0.22 & 0.98 \\
V6_Motiv & 0.93 & 0.37 \\
V7_FreeSoft & 0.78 & 0.63 \\
V8_InnAct & 0.95 & -0.32 \\
V9_IntDet & 0.73 & -0.68 \\
V10_ExtDet & 0.99 & 0.15 \\
& -0.24 & 0.97 \\
\hline \multicolumn{1}{c}{ Variables } & PC $\mathbf{1}$ & PC 2 \\
\hline V1_Struct & 0.97 & 0.23 \\
V2_Tools & 0.78 & 0.63 \\
V3_Strat & 0.98 & 0.18 \\
V4_Communic & 0.70 & -0.71 \\
V5_Leader & 1.00 & 0.04 \\
V6_Motiv & 0.32 & 0.95 \\
V7_FreeSoft & 1.00 & -0.03 \\
V8_InnAct & 0.99 & 0.12 \\
V9_IntDet & 0.89 & -0.45 \\
V10_ExtDet & -0.88 & 0.47 \\
\hline
\end{tabular}

If the analysis (PCA) of capabilities variables is applied to the groups of innovation impacts (low, medium and high), the first component explains $77 \%$ of the variability and, with the second, they reach the $100 \%$ (Table $4 \mathrm{~b}$ ). In the first component, the highest weights are represented by the variables V1_Struct, V3_Strat, V5_Leader, V7_FreeSoft and V8_InnAct. The second component is highly represented by the variable V6_Motiv (Tables $5 \mathrm{~b}$ and $6 \mathrm{~b}$ ).

It is important to note that in both analyzes, $100 \%$ of the variability with the first two components is explained. This shows that the intervening variables have a high correlation between them (Table $5 \mathrm{a}, \mathrm{b}$ and Table $6 a, b)$.

From the biplots graphs below, it can be affirmed that companies with high degree of results are distinguished from those of medium and low degrees by having higher degrees in the variables of V6_Motiv, V3_Strat, V5_Leader and V9_DetInt (Figure 1). The particular values of the indices of these variables can be seen in Table $7 \mathrm{a}$. 


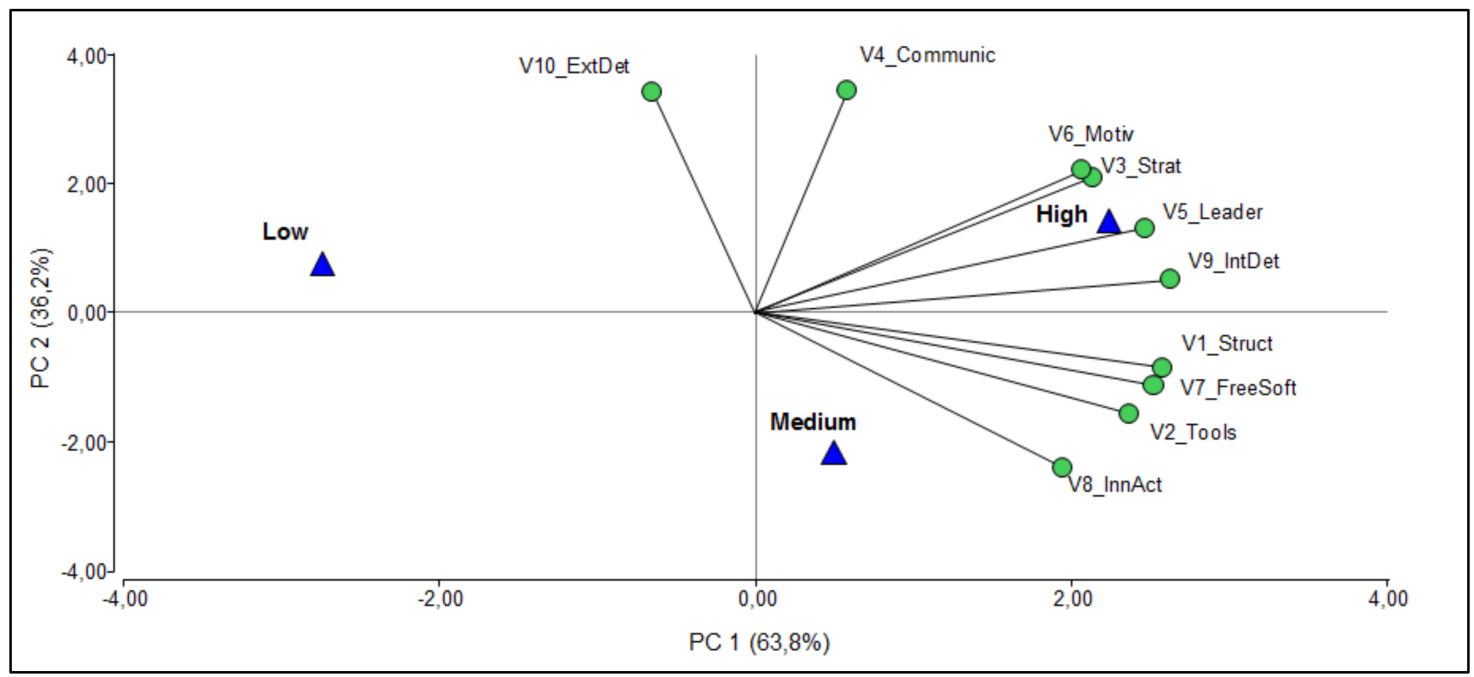

Figure 1. Biplot for the result groups and each of the capability variables.

Figure 2 illustrates the capabilities variables that distinguish companies with high impacts from those of medium and low degrees. These variables are: V1_Struct, V3_Strat, V5_Leader, V7_FreeSoft and V8_InnAct. The particular values of the indices of these variables can be seen in Table $7 \mathrm{~b}$.

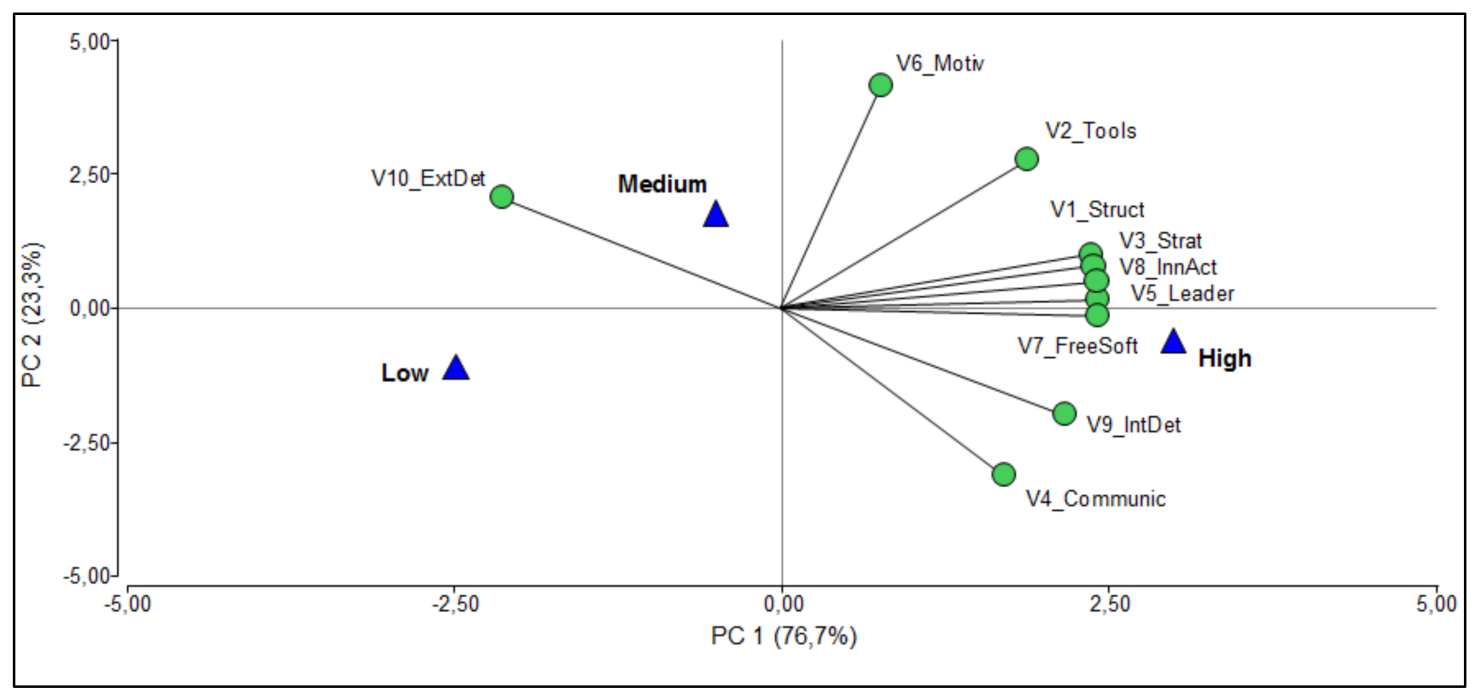

Figure 2. Biplot for the impact groups and each of the capability variables. 
Table 7. (a) Summary measures (mean, minimum and maximum) by variable for each degree of Results. (b) Summary measures (mean, minimum and maximum) by variable for each degree of Impacts.

\begin{tabular}{|c|c|c|c|c|c|c|c|c|c|c|c|c|c|c|c|}
\hline \multicolumn{16}{|c|}{ (a) } \\
\hline \multirow{2}{*}{ Result Degrees } & \multicolumn{3}{|c|}{ V1_Struct } & \multicolumn{3}{|c|}{ V2_Tools } & \multicolumn{3}{|c|}{ V3_Strat } & \multicolumn{3}{|c|}{ V4_Communic } & \multicolumn{3}{|c|}{ V5_Leader } \\
\hline & Mean & Min & Max & Mean & Min & Max & Mean & Min & Max & Mean & Min & Max & Mean & Min & $\operatorname{Max}$ \\
\hline High & 3.16 & 1.75 & 5.00 & 3.64 & 1.00 & 5.00 & 3.27 & 1.50 & 4.88 & 3.92 & 1.65 & 4.95 & 3.67 & 1.00 & 5.00 \\
\hline Medium & 3.13 & 1.60 & 4.85 & 3.70 & 1.00 & 5.00 & 3.11 & 1.38 & 4.00 & 3.83 & 0.99 & 4.95 & 3.37 & 1.00 & 5.00 \\
\hline Low & 2.85 & 1.45 & 4.70 & 3.17 & 1.00 & 5.00 & 3.10 & 1.50 & 4.50 & 3.89 & 1.32 & 4.95 & 3.23 & 1.00 & 5.00 \\
\hline \multirow{2}{*}{ Result Degrees } & \multicolumn{3}{|c|}{ V6_Motiv } & \multicolumn{3}{|c|}{ V7_FreeSoft } & \multicolumn{3}{|c|}{ V8_InnAct } & \multicolumn{3}{|c|}{ V9_IntDet } & \multicolumn{3}{|c|}{ V10_ExtDet } \\
\hline & Mean & Min & Max & Mean & Min & Max & Mean & Min & Max & Mean & Min & Max & Mean & Min & Max \\
\hline High & 3.02 & 1.00 & 5.00 & 4.18 & 2.00 & 5.00 & 2.92 & 1.00 & 4.60 & 3.78 & 2.00 & 4.60 & 3.15 & 1.65 & 4.35 \\
\hline Medium & 2.73 & 1.00 & 5.00 & 4.17 & 2.00 & 5.00 & 3.09 & 1.40 & 4.60 & 3.65 & 2.80 & 4.40 & 2.96 & 1.65 & 4.00 \\
\hline Low & 2.73 & 1.00 & 5.00 & 3.86 & 2.00 & 5.00 & 2.65 & 1.00 & 4.20 & 3.50 & 1.80 & 4.40 & 3.16 & 2.00 & 4.35 \\
\hline \multicolumn{16}{|c|}{ (b) } \\
\hline \multirow{2}{*}{ Impact Degrees } & \multicolumn{3}{|c|}{ V1_Struct } & \multicolumn{3}{|c|}{ V2_Tools } & \multicolumn{3}{|c|}{ V3_Strat } & \multicolumn{3}{|c|}{ V4_Communic } & \multicolumn{3}{|c|}{ V5_Leader } \\
\hline & Mean & Min & Max & Mean & Min & Max & Mean & Min & Max & Mean & Min & Max & Mean & Min & $\operatorname{Max}$ \\
\hline High & 3.25 & 1.60 & 4.85 & 3.76 & 1.00 & 5.00 & 3.60 & 2.38 & 4.63 & 4.25 & 2.64 & 4.95 & 3.60 & 2.00 & 5.00 \\
\hline Medium & 3.14 & 1.75 & 5.00 & 3.76 & 2.40 & 4.40 & 3.29 & 2.00 & 4.88 & 3.71 & 0.99 & 4.95 & 3.50 & 1.00 & 5.00 \\
\hline Low & 2.99 & 1.45 & 4.85 & 3.30 & 1.00 & 5.00 & 2.95 & 1.38 & 4.50 & 3.93 & 1.32 & 4.95 & 3.43 & 1.00 & 5.00 \\
\hline \multirow{2}{*}{ Impact Degrees } & \multicolumn{3}{|c|}{ V6_Motiv } & \multicolumn{3}{|c|}{ V7_FreeSoft } & \multicolumn{3}{|c|}{ V8_InnAct } & \multicolumn{3}{|c|}{ V9_IntDet } & \multicolumn{3}{|c|}{ V10_ExtDet } \\
\hline & Mean & Min & Max & Mean & Min & Max & Mean & Min & Max & Mean & Min & Max & Mean & Min & $\operatorname{Max}$ \\
\hline High & 2.87 & 1.00 & 5.00 & 4.27 & 2.00 & 5.00 & 3.37 & 1.40 & 4.40 & 3.92 & 3.40 & 4.60 & 3.05 & 1.65 & 4.35 \\
\hline Medium & 3.14 & 1.00 & 5.00 & 4.12 & 2.00 & 5.00 & 3.00 & 1.00 & 4.60 & 3.62 & 2.00 & 4.40 & 3.11 & 1.65 & 4.35 \\
\hline Low & 2.63 & 1.00 & 5.00 & 4.04 & 2.00 & 5.00 & 2.68 & 1.00 & 4.60 & 3.66 & 1.80 & 4.40 & 3.10 & 2.00 & 4.00 \\
\hline
\end{tabular}




\section{Discussion}

The present work is based on the interest for studying innovation capabilities in specific contexts, such as companies in the software sector operating in developing countries as Argentina.

Despite the breadth of the literature on innovation capabilities, there is no researches that focuses on identifying which capabilities in innovation management have developed companies with high innovation results and high innovation impacts.

Different studies have identified multiple variables that condition the ability to generate innovation (for example, Camio et al. 2016; or Lawson and Samson 2001). Based on the study carried out, it was possible to identify specifically those capabilities that software companies with high results and impacts of innovation have developed and that distinguishes them from companies with low and medium innovation results and impacts.

Applying the technique of Principal Components Analysis, it is highlighted that $100 \%$ of the variability is explained with the first two components for the analysis of groups according to the degree (low, medium and high) of results and impacts of innovation.

It is identified that companies with high results are characterized by having higher degrees in the variables of motivation and internal determinants. This supports the theoretical framework regarding the importance of aligning rewards and incentive systems with innovation objectives (Manso 2011; Sajeva and Jucevicius 2008) and focuses on internal factors such as culture (Baker et al. 2014; Aramburu and Sáenz 2010), background and skills, training and qualification of employees (Romero and Martínez-Román 2012; Koellinger 2008; Koc 2007; Romijn and Albaladejo 2002), among others.

Companies with high innovation impacts are characterized by higher degrees in the following variables: structure, free software and innovation activities. These results are in line with the contributions of different authors who recognize that structure is an important factor in promoting learning and innovation (Rueda-Cáceres and Sánchez-Torres 2015), identifying the consideration of innovation activities as a key aspect (Wagner 2011; OECD 2002) and studying the impact of the use of free software in the generation of innovation (Morgan and Finnegan 2014; Teigland et al. 2014).

Furthermore, two variables that distinguish companies with high results and impacts could be identified: strategy and leadership. The above affirms what is proposed in the theoretical framework, particularly in relation to the strategy by Tamm (2010; cited by Rueda-Cáceres and Sánchez-Torres 2015), Tellis et al. (2009) and Dobni (2008). Regarding leadership, the results obtained support the findings of Gumusluoglu and Ilsev (2009) about the impact of transformational leadership and its relationship with organizational innovation.

Considering the capabilities under study, particularly in the case of external determinants (which include the relationship with external actors and the identification of lower external barriers), it is understood that the inverse relationship identified would require a more in-depth analysis in the search for answers, among others, the degree of personal identification of external barriers for innovation in companies with different degrees of results and impacts.

These findings are in line with what is proposed by Drucker (1954; cited by Cavusgil et al. 2003) who points out that innovation capabilities are critical to achieving a superior innovation performance and that a firm with a great innovation capability will enjoy a high innovation performance. Also contribute elements to the theory of capabilities for innovation, in terms of its particularization with respect to the software sector, in a territory, Argentina and allow to consider the relative importance of the variables of capabilities in the generation of results and impacts of innovation.

This study contributes to the identification of key variables, in terms of capabilities, to be taken into account for diagnosis and intervention in the management of innovation in software companies, which has been possible given the potential of the applied methodology: Principal Component Analysis.

However, the methodological proposal of the present study, which is based on a specific model for the management of innovation in software companies, a methodology of data collection, analysis and 
synthesis through indices of different degrees, would make possible the replication of the study in other territorial contexts and would allow to include, in future analysis, other dimensions such as the size of the companies and study their relationship with the variables of results analyzed in the present work.

Author Contributions: These authors contributed equally to this work.

Conflicts of Interest: The authors declare no conflict of interest.

\section{References}

Abraham, Jay, and Daniel Knight. 2001. Strategic innovation: Leveraging creative action for more profitable growth. Strategy and Leadership 17: 21-27. [CrossRef]

Aiken, Michael, and Jerald Hage. 1971. The organic organization and innovation. Sociology 5: 63-82. [CrossRef]

Akinwale, Yusuf O., John-Felix K. Akinbami, and Joshua B. Akarakiri. 2018. Factors influencing technology and innovation capability in the Nigerian indigenous oil firms. International Journal of Business Innovation and Research 15: 247-68. [CrossRef]

Akman, Gülşen, and Cengiz Yilmaz. 2008. Innovative Capability, Innovation Strategy and Market Orientation: An Empirical Analysis in Turkish Software Industry. International Journal of Innovation Management 12: 69-111. [CrossRef]

Amabile, Teresa M., Regina Conti, Heather Coon, Jeffrey Lazenby, and Michael Herron. 1996. Assessing the work environment of creativity. Academy of Management Journal 39: 1154-1184. [CrossRef]

Amar, Amar D. 2004. Motivating knowledge workers to innovate: A model integrating motivation dynamics and antecedents. European Journal of Innovation Management 7: 89-101. [CrossRef]

Ambrosini, Véronique, Cliff Bowman, and Nardine Collier. 2009. Dynamic capabilities: An exploration of how firms renew their resource base. British Journal of Management 20: 9-24. [CrossRef]

Aragón-Correa, J. Alberto, and Sanjay Sharma. 2003. A contingent resource-based view of proactive corporate environmental strategy. Academy of Management Review 28: 71-88.

Aramburu, Nekane, and Josune Sáenz. 2010. Knowledge Sharing in Management Processes: Impact on Innovation Project Management and Innovation Performance. Paper presented at 11th European Conference on Knowledge Management ECKM, Vila Nova de Famalicao, Portugal, September 2-3.

Baker, William, James Sinkula, Amir Grinstein, and Stav Rosenzweig. 2014. The effect of radical innovation in/congruence on new product performance. Industrial Marketing Management 43: 1314-23. [CrossRef]

Balzarini, Mónica, Laura González, Margot Tablada, Fernando Casanoves, Julio A. Di Rienzo, and Walter Robledo. 2008. Infostat. Manual del usuario. Córdoba: Editorial Brujas.

Bass, Bernard M. 2000. The Future of Leadership in Learning Organizations. Journal of Leadership \& Organizational Studies 7: 18-40.

Benkler, Yochai. 2002. Coase's Penguin, or, Linux and the nature of the firm. Yale Law Journal 112: 369-446. [CrossRef]

Bigliardi, Barbara, and Francesco Galati. 2016. Which factors hinder the adoption of open innovation in SMEs? Technology Analysis \& Strategic Management 28: 869-85.

Börjesson, Sofia, and Hans Löfsten. 2012. Capabilities for innovation in small firms-A study of 131 high-tech firms and their relation to performance. International Journal of Business Innovation and Research 6: 149-176.

Brouwer, Erick, and Alfred Kleinknecht. 1999. Innovative output, and a firm's propensity to patent: an exploration of CIS micro data. Research Policy 28: 615-624. [CrossRef]

Brunswicker, Sabine, and Wim Vanhaverbeke. 2015. Open innovation in small and medium-sized enterprises (SMEs): external knowledge sourcing strategies and internal organizational facilitators. Journal of Small Business Management. forthcoming. [CrossRef]

Çakar, Nigar Demircan, and Alper Ertürk. 2010. Comparing innovation capability of small and medium-sized enterprises: Examining the effects of organizational culture and empowerment. Journal of Small Business Management 48: 325-59. [CrossRef] 
Camio, María Isabel, María del Carmen Romero, and María Belén Álvarez. 2015. Índice de nivel de innovación y sus componentes. Estudio en empresas argentinas de software. Paper presented at XVI Congreso da Associação Latino Ibero-Americana de Gestão de Tecnologia (ALTEC), Porto Alegre, Brasil, Octubre. Available online: http:/ /altec2015.nitec.co/altec/papers/857.pdf (accessed on 10 April 2018).

Camio, María Isabel, Alfredo Rébori, María del Carmen Romero, and María Belén Álvarez. 2016. Innovación y software: Diagnóstico y medición en empresas argentinas, 1st ed. Tandil: Editorial UNICEN.

Capaldo, Guido, Luca Iandoli, Mario Raffa, and Giuseppe Zollo. 2003. The Evaluation of Innovation Capabilities in Small Software Firms: A Methodological Approach. Small Business Economics 21: 343-54. [CrossRef]

Carter, Franklin J., Thani Jambulingam, Vipul K. Gupta, and Nancy Melone. 2001. Technological innovations: A framework for communicating diffusion effects. Information \& Management 38: 277-87.

Cavusgil, S. Tamer, Roger J. Calantone, and Yushan Zhao. 2003. Tacit knowledge transfer and firm innovation capability. Journal of business $\mathcal{E}$ industrial marketing 18: 6-21.

Chandy, Rajesh, and Gerard J. Tellis. 2000. The incumbent's curse? Incumbency, size and radical product innovation. Journal of Marketing 64: 1-17. [CrossRef]

Chang, Yi-Ying, Yaping Gong, and Mike W. Peng. 2012. Expatriate knowledge transfer, subsidiary absorptive capacity, and subsidiary performance. Academy of Management Journal 55: 927-48. [CrossRef]

Chang, Jeanine, Xuan Bai, and Julie Juan Li. 2015. The influence of leadership on product and process innovations in China: The contingent role of knowledge acquisition capability. Industrial Marketing Management 50: 18-29. [CrossRef]

Cheng, Colin, and Ja-Shen Chen. 2013. Breakthrough innovation: The roles of dynamic innovation capabilities and open innovation activities. Journal of Business and Industrial Marketing 28: 444-54. [CrossRef]

Cheng, Colin C. J., Chenlung Yang, and Chwen Sheu. 2016. Effects of open innovation and knowledge-based dynamic capabilities on radical innovation: An empirical study. Journal of Engineering and Technology Management 41: 79-91. [CrossRef]

Chesbrough, Henry. 2003. Open Innovation. The New Imperative for Creating and Profiting from Technology. Boston: Harvard Business School Press.

Clausen, Tommy Høyvarde. 2013. The role of operational and dynamic capabilities in ambidextrous innovation: A longitudinal analysis. Paper presented at 35th DRUID Celebration Conference 2013, Barcelona, Spain, June 17-19.

Cohen, Wesley M., and Daniel A. Levinthal. 1990. Absorptive Capacity: A New Perspective on Learning and Innovation. Administrative Science Quarterly 35: 128-52. [CrossRef]

Comin, Rafaele, Danile Sanches, and Francisco Uchoa. 2015. O processo de gestão da inovação: um estudo de caso nas empresas baianas do Polo de Informática de Ilhéus. Paper presented at XVI Congreso da Associação Latino Ibero-Americana de Gestão de Tecnologia (ALTEC), Porto Alegre, Brasil, Octubre 19-22.

Crossan, Mary M., and Marina Apaydin. 2010. A multi-dimensional framework of organizational innovation: A systematic review of the literature. Journal of Management Studies 47: 1154-91. [CrossRef]

Dahlander, Linus, and Martin W. Wallin. 2006. A man on the inside: Unlocking communities as complementary assets. Research Policy 35: 1243-59. [CrossRef]

Deeds, David L. 2001. The role of R\&D intensity, technical development and absorptive capacity in creating entrepreneurial wealth in high technology start-ups. Journal of Engineering and Technology Management 18: 29-47.

Di Rienzo, Julio A., Fernando Casanoves, Mónica Balzarini, Laura González, Margot Tablada, and Walter Robledo. 2016. InfoStat Versión 2016. Grupo InfoStat, FCA, Universidad Nacional de Córdoba, Argentina. Available online: http:/ / www.infostat.com.ar (accessed on 10 April 2018).

Dobni, Brooke C. 2008. Measuring innovation culture in organizations. The development of a generalized innovation culture construct using exploratory factor analysis. European Journal of Innovation Management 11: 539-59. [CrossRef]

Dolsen, Mark, and Ratna Babu Chinnam. 2017. Developing innovation capability in a mass production organization. Journal of Enterprise Transformation. [CrossRef]

Drucker, Peter. 1954. The Practice of Management. New York: Harper \& Row Publisher, Inc.

Eisenhardt, Kathleen M., and Jeffrey A. Martin. 2000. Dynamic capabilities: What are they? Strategic Management Journal 21: 1105-21. [CrossRef] 
Enkel, Ellen, Oliver Gassman, and Henry Chesbrough. 2009. Open R\&D and open innovation: Exploring the phenomenon. RED Management 39: 311-16.

Evan, William M., and Gay Black. 1967. Innovation in business organizations: some factors associated with success or failure of staff proposals. The Journal of Business 40: 519-30. [CrossRef]

Feller, Joseph, Patrick Finnegan, Brian Fitzgerald, and Jeremy Hayes. 2008. From peer production to productization: a study of socially enabled business exchanges in open source service networks. Information Systems Research 19: 1-19. [CrossRef]

Flor, María L., and María J. Oltra. 2004. Identification of innovating firms through technological innovation indicators: An application to the Spanish ceramic tile industry. Research Policy 33: 323-36. [CrossRef]

Gabriel, Kuno Ruben. 1971. Biplot display of multivariate matrices with application to principal components analysis. Biometrika 58: 453-67. [CrossRef]

Gassmann, Oliver, and Ellen Enkel. 2004. Towards a Theory of Open Innovation: Three Core Process Archetypes. Paper presented at R\&D Management Conference (RADMA), Lisbon, Portugal, July 7-9.

Gumusluoglu, Lale, and Arzu Ilsev. 2009. Transformational leadership, creativity and organizational innovation. Journal of Business Research 62: 461-73. [CrossRef]

Hadjimanolis, Athanasios. 2000. An investigation of innovation antecedents in small firms in the context of a small developing country. RED Management 30: 235-46.

Han, Jin K., Namwoon Kim, and Rajendra K. Srivastava. 1998. Market orientation and organizational performance: Is innovation the missing link? Journal of Marketing 62: 30-45. [CrossRef]

Hart, Stuart L., and Glen Dowell. 2010. A natural-resource-based view of the firm: Fifteen years after. Journal of Management 37: 1464-79. [CrossRef]

Helfat, Constance, Sydney Finkelstein, Will Mitchell, Margaret A. Peteraf, Harbir Singh, David Teece, and Sidney Winter. 2007. Dynamic Capabilities: Understanding Strategic Change in Organizations. Oxford: Blackwell.

Hilles, Afkar Qasem, Tee Ding Ding, and Pervaiz K. Ahmed. 2009. Managing for innovation and creativity: Organizational paradoxes in implementation practice. International Journal of Management Practice 3: 305-26. [CrossRef]

Hotho, Sabine, and Katherine Champion. 2011. Small Businesses in the new Creative Industries: Innovation as a People Management Challenge. Management Decision 49: 29-54. [CrossRef]

Iddris, Faisal. 2016. Innovation Capability: A Systematic Review and Research Agenda. Interdisciplinary Journal of Information, Knowledge and Management 11: 235-60. [CrossRef]

Indarti, Nurul. 2017. Impacts of external knowledge and interaction on innovation capability among Indonesian SMEs. International Journal of Business Innovation and Research 13: 430-50. [CrossRef]

Jaskyte, Kristina, and María Susana de Riobó. 2004. Characteristics of innovative nonprofit organizations in Argentina. Voluntas: International Journal of Voluntary and Nonprofit Organizations 15: 71-83. [CrossRef]

Jung, Dong I. 2001. Transformational and transactional leadership and their effects on creativity in groups. Creativity Research Journal 13: 185-95. [CrossRef]

Jung, Dong I., Chee Chow, and Anne Wu. 2003. The role of transformational leadership in enhancing organizational innovation: Hypotheses and some preliminary findings. The Leadership Quarterly 14: 525-44. [CrossRef]

Kandampully, Jay. 2002. Innovation as the core competency of a service organization: The role of technology, knowledge and networks. European Journal of Innovation Management 5: 18-26. [CrossRef]

Kanter, Rosabeth M. 1982. The middle manager as innovator. Harvard Business Review 60: 95-105. [PubMed]

Kanter, Rosabeth M. 1988. When a thousand flowers bloom: Structural, collective and social conditions for innovation in organization. In Research in Organizational Behavior. Edited by Barry M. Staw and L.L. Cummings. Greenwich: JAI Press, vol. 10, pp. 139-62.

Katz, Ralph. 1982. The effects of group longevity on project communication and performance. Administrative Science Quarterly 27: 81-104. [CrossRef]

Keller, Robert T. 1986. Predictors of the performance of project groups in R\&D organizations. Academy of Management Journal 29: 715-26.

Keller, Robert T., and Winford E. Holland. 1983. Communicators and innovators in research and development organizations. Academy of Management Journal 26: 742-49. [CrossRef] 
Keupp, Marcus Matthias, Maximilian Palmie, and Oliver Gassmann. 2011. The strategic management of innovation: A systematic review and paths for future research. International Journal of Management Reviews 14: 367-90. [CrossRef]

Kim, Dong-Young, Vinod Kumar, and Uma Kumar. 2012. Relationship between quality management practices and innovation. Journal of Operations Management 30: 295-315. [CrossRef]

Koc, Tufan. 2007. Organizational determinants of innovation capacity in software companies. Computers $\mathcal{E}$ Industrial Engineering 53: 373-85.

Koellinger, Philipp. 2008. Why are some entrepreneurs more innovative than others? Small Business Economics 31: 21-37. [CrossRef]

Kogut, Bruce, and Udo Zander. 1992. Knowledge of the Firm, Combinative Capabilities and the Replication of Technology. Organization Science 3: 383-97. [CrossRef]

Kohlbacher, Markus. 2013. The impact of dynamic capabilities through continuous improvement on innovation: The role of business process orientation. Knowledge and Process Management 20: 71-76. [CrossRef]

Lages, Luis Felipe, Silva Graca, and Chris C. Styles. 2009. Relationship capabilities, quality and innovation as determinants of export performance. Journal of International Marketing 17: 47-70. [CrossRef]

Lawson, Benn, and Danny Samson. 2001. Developing innovation capability in organisations: A dynamic capabilities approach. International Journal of Innovation Management 5: 377-400. [CrossRef]

Le Masson, Pascal, Benoit Weil, and Armand A. Hatchuel. 2010. Strategic Management of Innovation and Design. Cambridge: Cambridge University Press.

Leavy, Brian. 2005. A leader's guide to creating an innovation culture. Strategy E Leadership 33: 38-45.

Lemon, Mark, and Parminder Singh Sahota. 2004. Organizational culture as a knowledge repository for increased innovative capacity. Technovation 24: 483-98. [CrossRef]

Liao, Jianwen, Harold Welsch, and Michael Stoica. 2003. Organizational absorptive capacity and responsiveness: an empirical investigation of growth-oriented SMEs. Entrepreneur. Theory Pract 28: 63-85. [CrossRef]

Liao, Shu-Hsien, Chi-Chuan Wu, Da-Chian Hu, and Kuang-An Tsui. 2010. Relationships between knowledge acquisition, absorptive capacity and innovation capability: An empirical study on Taiwan's financial and manufacturing industries. Journal of Information Science 36: 19-35. [CrossRef]

Lin, Hai-Fen, Jing-Qin Su, and Angela Higgins. 2016. How dynamic capabilities affect adoption of management innovations. Journal of Business Research 69: 862-76. [CrossRef]

López, Andrés. 1998. La reciente literatura sobre la economía del cambio tecnológico y la innovación: una guía temática. IED. Revista de Industria y Desarrollo 1: 105-56.

López, Andrés, and Gustavo Lugones. 1997. El proceso de innovación tecnológica en América Latina en los años noventa. Criterios para la definición de indicadores. Redes. Revista de Estudios Sociales de La Ciencia IV: 13-48.

Manso, Gustavo. 2011. Motivating Innovation. The Journal of Finance 66: 1823-60. [CrossRef]

Martins, Ellen C., and Fransie Terblanche. 2003. Building organizational culture that stimulates creativity and innovation. European Journal of Innovation Management 6: 64-74. [CrossRef]

Medina, Carmen C., Antonio C. Lavado, and Ramón V. Cabrera. 2005. Characteristics of innovative companies: A case study of companies in different sectors. Creativity and Innovation Management 14: 272-87. [CrossRef]

Miranda, Eduardo, and Paulo N. Figueiredo. 2010. Dinâmica da acumulação de capacidades inovadoras: Evidências de empresas de software no Rio de Janeiro e em São Paulo. Revista de Administração de Empresas 50: 75-93. [CrossRef]

Monge, Peter R., Michael D. Cozzens, and Noshir S. Contractor. 1993. Communication and motivational predictors of the dynamics of organizational innovation. Organization Science 3: 250-74. [CrossRef]

Morgan, Lorraine, and Patrick Finnegan. 2014. Beyond free software: An exploration of the business value of strategic open source. Journal of Strategic Information Systems. [CrossRef]

Morgan, Lorraine, Joseph Feller, and Patrick Finnegan. 2013. Exploring value networks: theorising the creation and capture of value with open source software. European Journal of Information Systems 22: 569-88. [CrossRef]

Mostafa, Mohamed. 2005. Factors affecting organizational creativity and innovativeness in Egyptian business organizations: an empirical investigation. Journal of Management Development 24: 7-33. [CrossRef]

Mudrak, Tomas, Andreas van Wagenberg, and Emiel Wubben. 2005. Innovation process and innovativeness of facility management organizations. Facilities 23: 103-18. [CrossRef]

Mumford, Michael D., Ginamarie M. Scott, Blaine Gaddis, and Jill M. Strange. 2002. Leading creative people: Orchestrating expertise and relationships. The Leadership Quarterly 6: 705-50. [CrossRef] 
Muthusamy, Senthil Kumar, Jane V. Wheeler, and Bret L. Simmon. 2005. Self-managing work teams: Enhancing organizational innovativeness. Organization Development Journal 23: 53-67.

Nystrom, Paul C., Keshavamurthy Ramamurthy, and Alla L. Wilson. 2002. Organizational context, climate and innovativeness: Adoption of imaging technology. Journal of Engineering and Technology Management 19: 221-47. [CrossRef]

O'Conner, Gina Colarelli. 2008. Major innovation as dynamic capability: A system approach. Product Innovation Management 25: 313-30. [CrossRef]

OECD. 2002. Manual de Frascati 2002. París: Organización para la Cooperación y Desarrollo Económicos.

OECD and Eurostat. 2005. Manual de Oslo. Guía para la recogida e interpretación de datos sobre Innovación. Paris: OCDE-EUROSTAT.

Pavitt, Keith. 2002. Innovating routines in the business firm: What corporate tasks should they be. Industrial and Corporate Change 11: 117-33. [CrossRef]

Pelz, Donald C., and Frank M. Andrews. 1966. Scientists in Organizations. New York: John Wiley \& Sons.

Perdomo-Ortiz, Jesus, Gonzalez-Benito Javier, and Jesus Galende. 2006. Total quality management as a forerunner of business innovation capability. Technovation 26: 1170-85. [CrossRef]

Ralpha, Paavo, and Pia Hurmelinna-Laukkanen. 2013. Incremental and radical innovation in coopetition-the role of absorptive capacity and appropriability. Journal of Product Innovation Management 30: 154-69.

ReVelle, Jack B. 2010. Manufacturing of Best Practices: An Innovation, Productivity and Quality Focus. Boca Raton: CRC Press.

RICYT/OEA/CYTED/COLCIENCIAS/OCYT. 2001. Normalización de Indicadores de Innovación Tecnológica en América Latina y el Caribe. Manual de Bogotá. Bogotá: RICYT/OEA/CYTED/COLCIENCIAS/OCYT.

Ridder, A. 2011. Sensing and seizing open innovation: A capability-based approach. Paper presented at the DIME-DRUID ACADEMY Winter Conference 2011, Aalborg, Denmark, January 20-22.

Ritter, Thomas, and Hans Georg Gemunden. 2003. Network competence: Its impact on innovation success and its antecedents. Journal of Business Research 56: 745-55. [CrossRef]

Rohrbeck, René, and Hans Georg Gemunden. 2011. Corporate Foresight: Its three roles in enhancing the innovation capacity of the firm. Technology Forecasting and Social Change 78: 231-43. [CrossRef]

Romero, Isidoro, and Juan A. Martínez-Román. 2012. Self-employment and innovation. Exploring the determinants of innovative behavior in small businesses. Research Policy 41: 178-89. [CrossRef]

Romero, María del Carmen, Alfredo Rébori, and María Isabel Camio. 2010. Un índice para medir el nivel de innovación tecnológica en empresas intensivas en el uso de tecnología. RAI: Revista de Administração e Inovação 7: 5-20.

Romijn, Henny, and Manuel Albaladejo. 2002. Determinants of innovation capability in small electronics and software firms in southeast England. Research Policy 31: 1053-67. [CrossRef]

Rueda-Cáceres, Iván Mauricio, and Jenny Marcela Sánchez-Torres. 2015. Características para la medición de los facilitadores de gestión como componentes de la capacidad de innovación. Paper presented at XVI Congreso da Associação Latino Ibero-Americana de Gestão de Tecnologia (ALTEC), Porto Alegre, Brasil, Octubre 19-22.

Sajeva, Svetlana, and Robertas Jucevicius. 2008. Linking Knowledge Management and Organizational Innovativeness. Social Sciences 1: 50-58.

Samson, Danny, Marianne Gloet, and Prakash Singh. 2017. Systematic innovation capability: Evidence from case studies and a large survey. International Journal of Innovation Management, 21. [CrossRef]

Saunila, Minna. 2017. Innovation capability in achieving higher performance: Perspectives of management and employees. Technology Analysis \& Strategic Management 29: 903-16.

Smith, Marisa, Marco Busi, Peter Ball, and Robert van der Meer. 2008. Factors Influencing an Organisations ability to Manage Innovation: A Structured Literature Review and Conceptual Model. International Journal of Innovation Management 12: 655-76. [CrossRef]

Sorescu, Alina B., and Jelena Spanjol. 2008. Innovation's effect on firm value and risk: Insights from consumer packaged goods. Journal of Marketing 72: 114-32. [CrossRef]

Sorescu, Alina B., Rajesh K. Chandy, and Jaideep C. Prabhu. 2003. Sources and financial consequences of radical innovation: Insights from pharmaceuticals. Journal of Marketing 67: 82-99. [CrossRef]

Sulistyo, Heru. 2016. Innovation capability of SMEs through entrepreneurship, marketing capability, relational capital and empowerment. Asia Pacific Management Review 21: 196-203. [CrossRef] 
Tamm, Dorel. 2010. Alignment between factors of the innovation process and public sector innovation support measures: An analysis of Estonian dairy processors and biotechnology enterprises. Baltic Journal of Economics 10: 93-94.

Tang, H. K. 1999. An inventory of organizational innovativeness. Technovation 19: 41-52. [CrossRef]

Teece, David. 2007. Explicating dynamic capabilities: The nature and microfoundations of sustainable enterprise performance. Strategic Management Journal 28: 1319-50. [CrossRef]

Teece, David. 2010. Business models, business strategy and innovation. Long Range Planning 43: 172-94. [CrossRef]

Teece, David, and Gary Pisano. 1994. The Dynamic Capabilities of Firms: An Introduction. Industrial and Corporate Change 3: 537-56. [CrossRef]

Teece, David, Gary Pisano, and Amy Shuen. 1997. Dinamic Capabilities and Strategic Management. Strategic Management Journal 18: 509-33. [CrossRef]

Teigland, Robin, Paul M. Di Gangi, Björn-Tore Flåten, Elia Giovacchini, and Nicolás Pastorino. 2014. Balancing on a tightrope: Managing the boundaries of a firm-sponsored OSS community and its impact on innovation and absorptive capacity. Information and Organization 24: 25-47. [CrossRef]

Tellis, Gerard J., Jaideep C. Prabhu, and Rajesh K. Chandy. 2009. Radical Innovation across Nations: The Preeminence of Corporate Culture. Journal of Marketing 73: 3-23. [CrossRef]

Thamhain, Hans J. 1990. Managing technologically innovative team efforts toward new product success. The Journal of Product Innovation Management 7: 5-19. [CrossRef]

Tidd, Joe, John Bessant, and Keith Pavitt. 1997. Managing Innovation: Integrating Technological, Market and Organisational Change. Great Britain: John Wiley \& Sons Inc.

Tjosvold, Dean, and Leonard T. Mcneely. 1988. Innovation through communication in an educational bureaucracy. Communication Research 15: 568-81. [CrossRef]

Un, Annique C. 2002. Innovative capability development in US and Japanese firms. Academy of Management Proceedings IM: E1-6. [CrossRef]

Wagner, Marcus. 2011. Acquisition as a means for external technology sourcing: Complementary, substitutive or both? Journal of Engineering and Technology Management 28: 283-99. [CrossRef]

West, Joel. 2007. Value capture and value networks in open source vendor strategies. Paper presented at the 40th Annual Hawaii International Conference on System Sciences (HICSS’07), Big Island, Hawaii, January 3-6.

Yin, Robert. 2009. Case Study Research. Design and Methods. Thousand Oaks: Sage.

Zhao, Hongxin, Xuesong Tong, Poh K. Wong, and Jishan Zhu. 2005. Types of technology sourcing and innovative capability: An exploratory study of Singapore manufacturing firms. Journal of High Technology Management Research 16: 209-24. [CrossRef]

Zwetsloot, Gerard. 2001. The management of innovation by frontrunner companies in environmental management and health and safety. Environmental Management and Health 12: 207-14. [CrossRef] 